\title{
Lights, camera, yoga and Ayurveda
}

Volume 4 Issue 5 - 2016

\section{Opinion}

I will never forget studying yoga and Ayurveda a decade ago while working in the film business, primarily in television commercials, and while shivering on an all night job. I was thinking, "My work-life is not meshing with my new yoga-inspired-and-acquired knowledge or mind-frame." I was sniffling a lot with the beginnings of a cold or flu after working back-to-back nights on the cold streets of Downtown LA as a taxi-driver on a big budget film. It was quite challenging staying awake all night on a side street with a two-way radio to my ear waiting to be called in for a driving scene. I ended up sipping a strong express to stay awake and struggled with an already weakened immunity. Welcome to the glamorous side of filmmaking.

While job growth in the Entertainment business as a whole has been on an upswing since about 2005, California has actually lost employment while other cities, notably New York, have made gains from the increase in film productions. Recent statistics by The Millikin Institute say that since 2005, California has lost some 4500 jobs, while cities like New York added 13,000. Employment losses have been especially notable in areas like one-hour network drama series and also big budget feature films, which are expensive to be made here. A worrisome trait that is also happening is that cities like New Orleans, Atlanta and Albuquerque are building up their "production ecosystems" including the building of soundstages and of good talent and crews. States are luring away productions with generous rebate and tax incentives. This can take moms and dads away from their families and is very common now; I know many in the industry who travel quite frequently and can be gone for months at a time. One needs to be prepared physically, mentally and emotionally for this work. There is the glamorous façade to the Biz, but also the freeze and work your ass off reality too. You could be going to a cold desert location where the wind is howling or a soundstage where smoke machines are pumping in smoke to diffuse lighting, not healthy or hospitable environments sometimes. This is why a personal yoga practice and some ayurvedic tools can serve all of us who work in this ever-changing film business climate, and hopefully help us stay grounded, healthy, and happy. I always remember someone telling me, "You don't measure success in wealth but in happiness, and happy people live longer." Om to that!

Thankfully, there are many practices that will benefit us on the road to sustained health while out on location that entail paying special attention to one's Daily Activities, Food and Diet, and Mind and Emotions, all essential to our wellbeing.

"He who indulges in healthy foods and activities, who discriminates (the good and bad of everything and then acts wisely), who is not attached (too much), to the objects of the senses, who develops the habit of charity, of considering all as equal (requiring kindness), of truthfulness, of pardoning and keeping company of good persons only, becomes free of diseases." (Ashtanga Hrdayam Chapter 4: 36).

\section{Daily activities}

Most likely you will go to a parking lot to get in a passenger van to be transported to location somewhere. Make sure to give

\section{Guy Gabriel CYT \\ Yoga Therapists, Bridge Yoga and health care, USA}

\begin{abstract}
Correspondence: Guy Gabriel CYT,The international association of Yoga Therapists, Bridge Yoga and health care, USA,
\end{abstract} Email guygabrielyoga@yahoo.com

Received: November 17, 2016 | Published: December 06, 2016

yourself ample time to get prepared for the day or night; slow breathing exercises are a good way to calm you. I cannot tell you the importance of having good base layers of clothing for warmth, and Patagonia and North face are the choice of professionals. Have a couple pairs if you need to double up and you probably will in certain environments. Have ski gloves and warm headgear. The same goes for a larger Patagonia/North face winter jacket. Most of the time there will be long days on the set so keep a few bags of nuts or fitness bars in your pockets for energy, and snack on fruits and H20 at craft service. Watch over-consuming coffee, sodas or fruity drinks; teas are always available as are vitamin $C$ packs. Because of the hurried pace usually on sets, find an activity after wrap that entails slower calming qualities like restorative yoga or a warm Jacuzzi tub. If you have a meditative practice, continue unabated. If not, listen to calming music and cultivate practices that balance out a hurried and busy day. Get to sleep at a decent time so as to be prepared for the next day's shoot. Remember that lots of traveling or moving from location to location aggravates and increases vata (air \& ether) in our mind and bodies. Anxiety about flying will do the same. Take steps to pacify vata on your shoot, and try to avoid alcohol as it increases dehydration. Think small routines like oil massage with warming oil after your shower in the hotel and nasya oil in the nostrils when feeling stressed on set. All small routines or Mindful practices add up and support your body's resilience.

"Taken in appropriate quantity, food certainly helps the individual in bringing about strength, complexion, happiness, and longevity without disturbing the equilibrium of dhatus (tissues) and doshas of the body." (Charaka Samhita Chapter 5: 8).

\section{Food and diet}

Ayurveda teaches us that whatever we eat determines how healthy and vibrant we are. All matter consists of the 5 elements and our food carries both subtle energetic qualities related to its production as well as its gross physical form. Making a connection between the qualities of the foods we're eating and the impact on our health is not always easy at first, and there are varied complexities to be considered. We have no idea today if GMO's are present in our food on the set, what kinds of oils are being used to cook, or how much salt or sugar, so being discerning about what you eat is essential as some foods will be easier to digest better than others. A great trend I've recently seen on 
sets is fresh fruit and vegetable juicing which is always a sure way to get powerful nutrients into your body. I'm also partial to a white egg veggie scramble with grainy toast; oatmeal is also always available, so eating warm in the morning can help balance vata. Be wise not to eat too many spicy foods, as having acid-reflux or Gerds is no fun on set. I usually keep some Banyan Pitta Digest tabs with me in case that happens but staying away from the varied hot sauces and salsas would be a smarter choice. Always bring a travel thermos or Libre Travel Cup for refilling with water or hot teas, which helps generating less waste with plastic bottles or cups. I always carry Organic India Tulsi teas also for digestion or relaxation. Come prepared so as to keep your doshas in balance and have strength and stamina through the production.

"According to the Acharyas the mind of a person is qualified on the basis of the type of his repeated action; it is so because that quality must be predominating in him." (Caraka Samhita 8: 6).

\section{Mind and emotions}

According to Ayurveda, all illnesses and imbalances are psychosomatic. We cannot separate our Body from our Mind and vice versa; both need to be considered when maintaining or restoring one's health and overall wellness. It can be sometimes quite challenging on set with so many different people of all doshic persuasions coming together to create works of cinematic art. Many different people with varied skills are needed and all must find a collaborative spirit. Directors can lose tempers and then everyone is on edge. Long 16 hour workdays fray nerves and test ones stamina and mental stability. Life on set is about relationships with your crew and cast, and the qualities of your emotions in these relationships affect your doshic balance. If there is lots of anger or agitation, then pitta will increase; fear and worry provoke vata; and possessiveness disturbs kapha. Negative emotions drain us of our pranic energy and affect and weaken our vital organs. When you deal with challenging situations on set, learn to be the observer. Try to see what is happening without judging, as many human interactions and communication can be fogged by past memories of hurts and judgmental attitudes. The little voice we hear in our individual heads is good at interfering with our minds' clarity, clouding our perceptions and actions. Be aware of its patterns, usually you will hear repetitive thoughts that are unloving and critical of yourself. Even if you cannot stop it, you can begin to mindfully change its tone to positive and loving messages. Every time you catch yourself having some negative thoughts and emotions, observe yourself and create a positive thought. In time we can rewire our minds to create beneficial habits that are healing us daily.

"The bad effects diminished gradually and the good effects increased gradually, attain (the state of) non-recurrence and become stable."

An important step in maintaining good health is to make sure to have strong digestion (Agni), which prevents improperly digested food (Ama), and builds healthy tissues (dhatus), which will result in sufficient immunity (Ojas). Ojas, if not depleted through a stressful and poor lifestyle, will give you great immunity physically and mentally. This good immunity will guard you and make you more resilient to doshic influences that you encounter on and off the set. When you are not having doshic imbalances, remember to follow a diet and lifestyle that will pacify your dominant dosha or doshas. This will help you maintain a better doshic balance, thereby preventing many ailments, increasing vitality and luster, and slowing down the inevitable aging process. Remember that life and work define us and give us purpose, but do not forget your responsibility to the higher unfolding of your spirit and its wellbeing and growth.

"Vayu (vata), pitta, and kapha are the three doshas, in brief; they destroy and support (sustain, maintain) the body when they are abnormal and normal respectively." (Ashtanga Hrdayam Chapter 1: 6).

\section{Acknowledgments}

None.

\section{Conflicts of interest}

Author declares there are no conflicts of interest.

\section{Funding}

None. 